\title{
Enhancement of the compliance to the updated Egyptian mental health law, a six sigma breakthrough project
}

\section{Introduction}

Compliance to the updated Mental Health law is a quality concern, though primarily is a medico legal one.

In medical ethics, the principle of a patient's self-determination obliges the physician to obtain the patient's consent prior to medical treatment. A condition for valid informed consent is the patient's competence, which may be impaired, particularly in patients with mental problems. In most cases, if the situation causes the physician to examine competence, he will proceed using his own subjective judgment and clinical experience and has difficulty applying standards suggested in the literature. Physicians also often evaluate competence differently. The admission for treatment should be authorized by a psychiatrist and audited from the National/ local Counsel of Mental Health within one week, reporting defects. ${ }^{1}$

\section{Definitions}

I. The term competence to consent refers to an individual's legal capacity to accept a proposed treatment, to refuse treatment, or to select among treatment options.

II. Voluntary admission: should base on patient's competence and free Volition to give informed written consent. The patient has the right to ask for being discharged.

III. Involuntary admission: conditioned with Presence of apparent signs and symptoms of severe mental illness, serious risky symptoms impacting the safety, health or life of the patient or the others or possibility of impending sever deterioration of the mental status. $^{2}$

IV. Medical Abbreviations:

a) BPRS: brief psychiatric rating scale measurement tool

b) GAF: global functioning assessment tool

c) HCR-20: history, clinical picture, risk management assessment scale

\section{Hard benefits}

I. Compliance to the law prevents legal consequences.

Table I Customer segmentation

\author{
Volume 7 Issue I - 2019
}

\author{
Amr M Elghazali,' Mahmoud El Damaty,' \\ Dina A Shokry, ${ }^{3}$ Ahmed Dobie ${ }^{4}$ \\ 'Certified Independent Medical Examiner (ABIME), Egypt \\ ${ }^{2} \mathrm{AUC}$ Business School - Executive Education Instructor, Egypt \\ ${ }^{3}$ Professor and head of Forensic Medicine Department, Faculty \\ of Medicine, Cairo University, Egypt \\ ${ }^{4}$ Professor and Consultant of Psychiatry, Egypt
}

Correspondence: Amr M Elghazali, Certified Independent Medical Examiner (ABIME), Egypt,

Email ghazali_dr_amr@hotmail.com

Received: January 23, 2018 | Published: January II, 2019

II. Decrease patient complaints Increasing the effective utilization of time by decreasing chances of re-do.

III. Increasing the total hospital's revenue

IV. Save money payed in court sue and malpractice claims.

V. Minimizing ineffective services.

VI. +Minimizing defective services.

\section{Soft benefits}

i. Improve professional image within the Regional/National Counsel.

ii. Increase the public image of the hospital in the community.

iii. Increase confidence of the customers, internal and external.

iv. Increase the awareness of the employees

v. Facilitate quest for accreditation.

\section{Situational analysis}

Compliance to the mental health law project has been selected by Quality Council after identification of the internal process defects through the auditing reports by the National/regional Counsel of Mental Health Table $1 .^{3}$

\begin{tabular}{|c|c|c|c|c|c|c|c|c|c|c|c|}
\hline & Feb & Mar & Apr & May & Jun & Jul & Aug & Oct & Nov & December & Total \\
\hline Total Number of patients & 100 & 100 & 100 & 100 & 100 & 100 & 100 & 100 & 100 & 100 & 1000 \\
\hline Schizophrenia & 7 & 5 & 3 & 5 & 7 & 12 & 23 & 9 & I & 10 & 82 \\
\hline Bipolar & I & 2 & 2 & 6 & 2 & 7 & 9 & I & 0 & 6 & 36 \\
\hline depression & 2 & 0 & 4 & 3 & 0 & 5 & I & 2 & 0 & 3 & 20 \\
\hline Personality disorder & 3 & 0 & I & 4 & 3 & 6 & 2 & I & 4 & 0 & 24 \\
\hline addiction & I & 2 & 1 & 0 & 2 & 4 & 6 & 5 & I & 6 & 28 \\
\hline Obsessive Compulsive Neurosis OCN & I & 0 & I & 0 & 0 & 2 & I & 2 & 3 & 0 & 10 \\
\hline Total No. of reported Non Compliance & 15 & 9 & 12 & 18 & 14 & 36 & 42 & 20 & 9 & 25 & 200 \\
\hline
\end{tabular}




\section{Sigma level calculation}

According to data collected during the $01-02-2017$ to $30-12-2017$ :
i. Total number of units $=1000$ Cases
ii. Opportunities for defect per unit $=10$
iii. Numbers of defects (non-compliance) $=200$
iv. $\mathrm{DPU}=200 / 1000=0.2$
v. $\mathrm{DPO}=200 / 1000 \times 1 / 10=0.02$
vi. $\mathrm{DPMO}=20000$
vii. Sigma level $=3.55$ (Yield 98\%).

\section{Steps of a six sigma project}

\section{Define phase}

\section{i. Team selection}

The quality council has selected a Cross Functional Team that will be compromised of the Following members:
i. Medical director
ii. Quality specialist
iii. Psychiatrist, resident
iv. Psychologist, resident
v. Nurse of the shit
vi. Administrator of the shift
vii. Forensic Psychiatrist, six sigma belt.

\section{Project mission statement}

\section{Problem statement}

It is a common concept that psychiatric patients are generally lacking the competence necessary for making treatment decision and the association with clinical and legal variables such as psychiatric illness, illness severity and involuntary admission that are usually assumed to be enough for the involuntary admission. Insight, as a conclusion from the symptoms is the strongest discriminator of competence and usually mistaken as the same concept for the competence though, this is not the matching the conditions of the Egyptian Mental Health law.

\section{Objectives}

To establish proper policies and procedures for the compliance with the Egyptian Mental Health Law and increase the sigma level of the process up to 4.5 sigma within 10 months starting 01/02/2017.

\section{Project goals}

I. To improve the performance by more compliance to the conditions of the Egyptian Mental Health Law conditions that regulating the admission and restricting the involuntary admission to that condition.

II. To reduce the non- compliance reports from the National and Regional counsel of Mental Health by $75 \%$ within one year after finding the root cause and the remedy for improvement.
III. A six-sigma approach was used to achieve the compliance to the legal standards for competence to consent to or refuse admission. ${ }^{4}$

\section{Mission verification process}

The cross functional team have verified the mission to recognize and acknowledge that it is Specific task related to the admission process outcome, Measurable as it is linked to the steps of the admission to be monitored and inspected, Attainable, as the leadership approval and support is gained with a supportive to neutral behavior of the hospital staff. This is a Reasonable one because the data is already available and the defined Time table is 10 months, from Feb $1^{\text {st }} 2017$ to December, $1^{\text {st }} 2017$. The team members have verified the mission statement with the quality council with SMART attributes. The team members shall be liable to sign the project charter devised by the sponsor under delegated authority from the council.

\section{Voice of customer}

\section{External customers}

\section{Primary data} reports

Drawn from the National and Regional Mental Health council

\section{Secondary data}

i. Direct observation and data collected from the quality department and the team members in favor of the project on the issue of not in compliance with the Egyptian Mental Health Law

ii. Data collected about number of non-compliance for the law for 10 months (From Feb, $1^{\text {st }} 2017$ to December, $1^{\text {st }} 2017$ ).

\section{Internal customer}

The VOC have been obtained by Table 2 :

i. Direct observation through reading the counsel auditing reports (the reports include the defects and dis-satisfaction comments).

ii. Interviews with the senior psychiatrist.

iii. Focus group (Resident psychiatrist and Psychologist, the Specialized Nurse and the Administrator) (Figure $1 \&$ Table 3).

Table 2 Internal customer

\begin{tabular}{ll}
\hline Customer Type & $\begin{array}{l}\text { VOC (The patient's or the counsel's } \\
\text { voice in-behave of the patients) }\end{array}$ \\
\hline $\begin{array}{l}\text { Schizophrenia } \\
\text { Bipolar Disorder }\end{array}$ & The counsel reported non compliance \\
Depression & The counsel reported non compliance \\
Personality disorder & The counsel reported non compliance \\
Addiction & The counsel reported non compliance \\
Obsessive Compulsive & The counsel reported non compliance \\
Neurosis OCN &
\end{tabular}




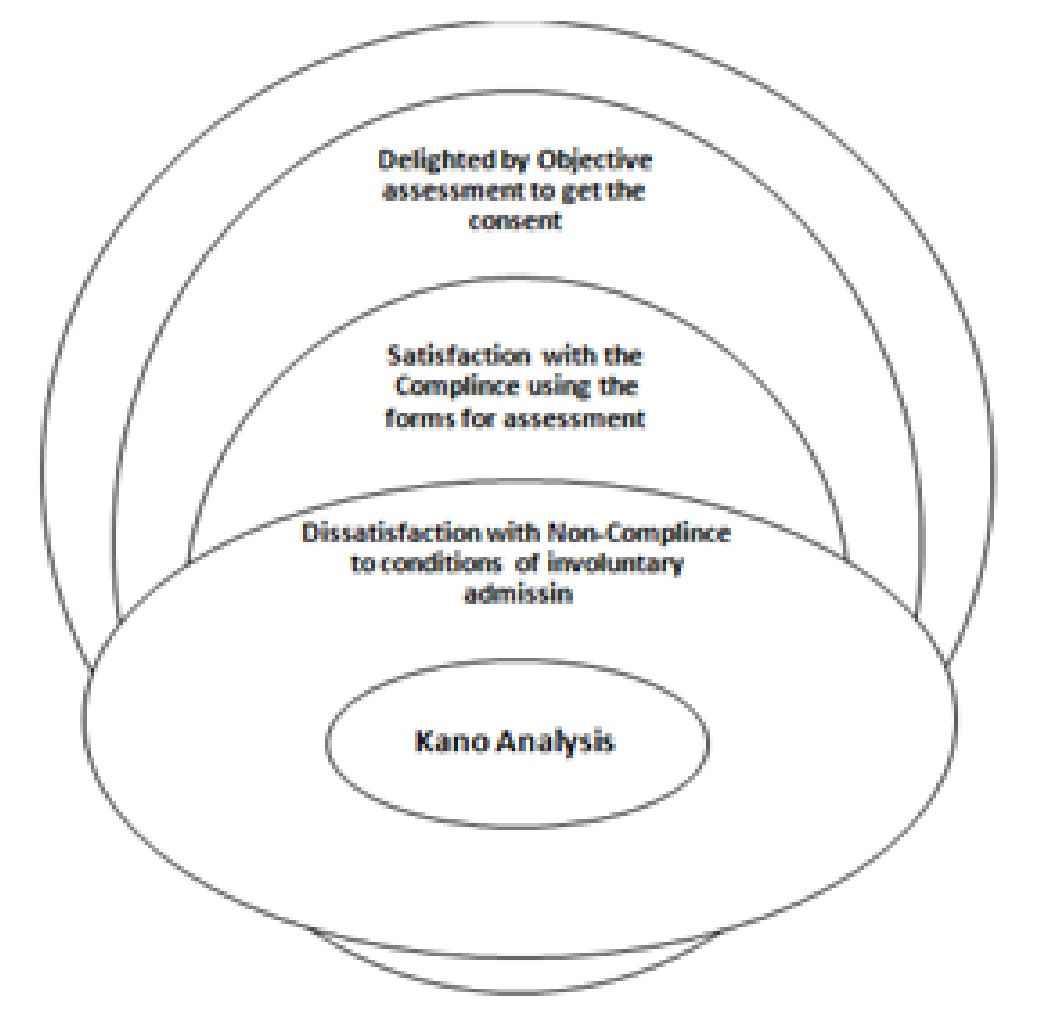

Figure I Kano analysis.

Table 3 Project Charter

\section{Business Case}

-The reported non-compliance to admission rules in the law have had financial consequences in the form of fine penalties and official announcements declared to professional and public media.

-The average cash loss that is directly related to the fines

and decrease patient flow, is estimated by almost

I,000,000 LE (One Million Egyptian Pounds) annually.

\section{Goal Statement}

I. Reduce the Customer dissatisfaction (The patients and the counsel) and Increase sigma level up to 4.5

2. mprove the process of admission and reduce non-compliance rate

\section{Project Plan}

- Define phase:

From $01 / 02 / 2017$ till 31/03/2017

- Measure Phase :

From $01 / 04 / 2017$ till 3I/05/20I7

- Analyze phase :

From 01/06/2017 till 31/07/2017

- Improve phase:

From $01 / 08 / 2017$ till 30/09/20I7

- Control Phase :

\section{Problem Statement (opportunity)}

The average rate The process is currently running at six sigma level $=3.55$

\section{Project Scope}

To improve existing Hospital's Admission processes, Six Sigma uses a five-phases DMAIC methodology that helps to Define, Measure, Analyze, Improve, and Control process capability.

\section{Team Selection}

The quality council has selected a Cross Functiona Team that will be compromised of the following members:

I- Psychiatrist (senior and resident)

2- Psychologist

3- Forensic Psychiatrist (six sigma belt)

4- Nurse

5- Administrator

From $01 / 10 / 2017$ till $01 / 12 / 2017$

Citation: Elghazali AM, El Damaty M, Shokry DA, et al. Enhancement of the compliance to the updated Egyptian mental health law, a six sigma breakthrough project. Forensic Res Criminol Int J. 2019;7(I):I6-23. DOI: I0.15406/frcij.2019.07.00259 


\section{Measure phase}

\section{Data sampling}

Data collection has been implemented by data collection sheets that have been authorized, stamped and verified by the quality department (Table 4) and (Figure 2).

Table 4 Sipoc

\begin{tabular}{|c|c|c|c|c|}
\hline Supply & Inputs & Process & Output & Customer \\
\hline $\begin{array}{l}\text { Family } \\
\text { Senior } \\
\text { Psychiatrist }\end{array}$ & $\begin{array}{l}\text { Assessment } \\
\text { of } \\
\text { symptoms } \\
\text { severity }\end{array}$ & $\begin{array}{l}\text { BBRS } \\
\text { assessment } \\
\text { scale }\end{array}$ & $\begin{array}{l}\text {-Voluntary } \\
\text { admission } \\
\text {-Involuntary } \\
\text { admission }\end{array}$ & $\begin{array}{l}\text {-Inpatient } \\
\text { Department } \\
\text {-Patient } \\
\text {-Family } \\
\text {-Auditing } \\
\text { Council }\end{array}$ \\
\hline $\begin{array}{l}\text { Family } \\
\text { Psychologist }\end{array}$ & $\begin{array}{l}\text { Assessment } \\
\text { of } \\
\text { Cognitive } \\
\text { Functions }\end{array}$ & $\begin{array}{l}\text { GAF } \\
\text { assessment } \\
\text { scale }\end{array}$ & $\begin{array}{l}\text { Voluntary } \\
\text { admission } \\
\text {-Involuntary } \\
\text { admission }\end{array}$ & $\begin{array}{l}\text {-Inpatient } \\
\text { Department } \\
\text {-Patient } \\
\text {-Family } \\
\text {-Auditing } \\
\text { Council }\end{array}$ \\
\hline $\begin{array}{l}\text { Specialized } \\
\text { Nurse } \\
\text { Family }\end{array}$ & $\begin{array}{l}\text { Risk } \\
\text { Assessment }\end{array}$ & $\begin{array}{l}\text { HCR- } \\
20 \text { Risk } \\
\text { Assessment } \\
\text { scale }\end{array}$ & $\begin{array}{l}\text {-Voluntary } \\
\text { admission } \\
\text {-Involuntary } \\
\text { admission }\end{array}$ & $\begin{array}{l}\text {-Inpatient } \\
\text { Department } \\
\text {-Patient } \\
\text {-Family } \\
\text {-Auditing } \\
\text { Council }\end{array}$ \\
\hline $\begin{array}{l}\text { Administrator } \\
\text { Family }\end{array}$ & $\begin{array}{l}\text { Addiction } \\
\text { Questioner }\end{array}$ & $\begin{array}{l}\text { Addiction } \\
\text { Profile } \\
\text { assessment } \\
\text { scale }\end{array}$ & $\begin{array}{l}\text {-Voluntary } \\
\text { admission } \\
\text {-Involuntary } \\
\text { admission }\end{array}$ & $\begin{array}{l}\text {-Inpatient } \\
\text { Department } \\
\text {-Patient } \\
\text {-Family } \\
\text {-Auditing } \\
\text { Council }\end{array}$ \\
\hline $\begin{array}{l}\text { Resident } \\
\text { psychiatrist } \\
\text { Family }\end{array}$ & $\begin{array}{l}\text { Consent } \\
\text { for } \\
\text { admission }\end{array}$ & $\begin{array}{l}\text { Direct } \\
\text { question } \\
\text { and answer } \\
(\mathrm{Y} / \mathrm{N})\end{array}$ & $\begin{array}{l}\text {-Voluntary } \\
\text { admission } \\
\text {-Involuntary } \\
\text { admission }\end{array}$ & $\begin{array}{l}\text {-Inpatient } \\
\text { Department } \\
\text {-Patient } \\
\text {-Family } \\
\text {-Auditing } \\
\text { Council }\end{array}$ \\
\hline
\end{tabular}

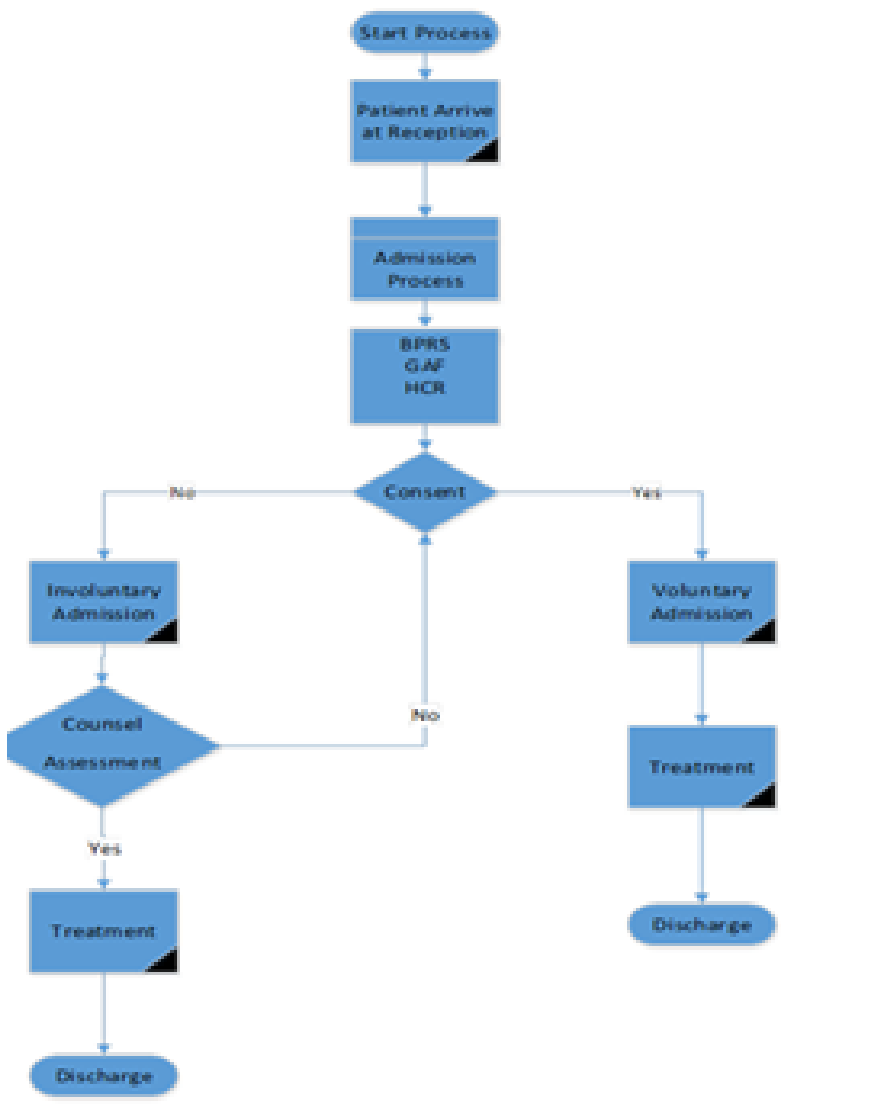

Figure 2 Detailed flow chart before improvement.

\section{Objective was to use the sample group for}

i. Extracting possible root causes of the noncompliance to the law and use the current data as a base for improvement.

ii. Using the improved data derived from the improved process as a base for the control to be plotted on the control chart (Table 5) \& (Table 6).

Table 5 Data collection forms

\begin{tabular}{|c|c|c|c|c|c|}
\hline Project Name & \multicolumn{5}{|c|}{ Six sigma breakthrough project to enhance compliance to the updated Egyptian Mental Health Law. } \\
\hline Process Name & \multicolumn{5}{|c|}{$\begin{array}{l}\text { Increase the compliance to the mental health law in the hospital admission process through the proper application of the } \\
\text { objective tools. }\end{array}$} \\
\hline Data Plan prepared by & \multicolumn{5}{|c|}{ Quality Improvement Unit, Quality Management Department } \\
\hline Time interval & \multicolumn{5}{|c|}{ From Ist Feb 2017 to Ist December 2017} \\
\hline Potential error & Operational definition & $\begin{array}{l}\text { Responsible person for } \\
\text { data recording }\end{array}$ & $\begin{array}{l}\text { When to collect } \\
\text { data }\end{array}$ & $\begin{array}{l}\text { How data is } \\
\text { recorded }\end{array}$ & Where data is recorded \\
\hline Senior Psychiatrist & $\begin{array}{l}\text { Assessment of symptoms' } \\
\text { severity }\end{array}$ & $\begin{array}{l}\text {-The medical director } \\
\text {-A copy sent to counsel }\end{array}$ & $\begin{array}{l}\text { Emergency } \\
\text { reception room }\end{array}$ & $\begin{array}{l}\text { BPRS assessment } \\
\text { scale form }\end{array}$ & $\begin{array}{l}\text {-Medical Records } \\
\text {-Copy to the counsel }\end{array}$ \\
\hline Psychologist & $\begin{array}{l}\text { Assessment of Cognitive } \\
\text { Functions }\end{array}$ & $\begin{array}{l}\text {-The medical director } \\
\text {-A copy sent to counsel }\end{array}$ & $\begin{array}{l}\text { Pre-Admission } \\
\text { room I }\end{array}$ & $\begin{array}{l}\text { GAF assessment } \\
\text { scale form }\end{array}$ & $\begin{array}{l}\text { Medical Records } \\
\text {-Copy to the counsel }\end{array}$ \\
\hline Specialized Nurse & $\begin{array}{l}\text { Assessment of Risk } \\
\text { Probability }\end{array}$ & $\begin{array}{l}\text {-The medical director } \\
\text {-A copy sent to counsel }\end{array}$ & $\begin{array}{l}\text { Pre-Admission } \\
\text { room I }\end{array}$ & $\begin{array}{l}\text { HCR-20 } \\
\text { assessment scale } \\
\text { form }\end{array}$ & $\begin{array}{l}\text {-Medical Records } \\
\text {-Copy to the counsel }\end{array}$ \\
\hline Administrator & Addiction questionnaire & $\begin{array}{l}\text {-The medical director } \\
\text {-A copy sent to counsel }\end{array}$ & $\begin{array}{l}\text { Pre-Admission } \\
\text { room } 2\end{array}$ & $\begin{array}{l}\text { Addiction } \\
\text { Questionnaire } \\
\text { scale form }\end{array}$ & $\begin{array}{l}\text {-Medical Records } \\
\text {-Copy to the counsel }\end{array}$ \\
\hline Resident Psychiatrist & $\begin{array}{l}\text { Asking for the consent for } \\
\text { admission }(\mathrm{Y} / \mathrm{N})\end{array}$ & $\begin{array}{l}\text {-The medical director } \\
\text {-A copy sent to counsel }\end{array}$ & $\begin{array}{l}\text { Pre-Admission } \\
\text { room } 3\end{array}$ & $\begin{array}{l}\text { Written Consent } \\
\text { form }(\mathrm{Y} / \mathrm{N})\end{array}$ & $\begin{array}{l}\text {-Medical Records } \\
\text {-Copy to the counsel }\end{array}$ \\
\hline
\end{tabular}


Table 6 Check sheet

\begin{tabular}{lll}
\hline Month & Frequency of defects & Tally \\
\hline Feb 2017 & 15 & IIIIIIIII IIII \\
Mar 2017 & 9 & IIIII IIII \\
Apr 2017 & 12 & IIIIIIIIII I \\
May 2017 & 18 & IIIIIIIIIIII IIII \\
Jun 2017 & 14 & IIIIIIIIIIII \\
Jul 2017 & 36 & IIIIIIIIIIIIII II \\
Aug 2017 & 42 & IIIIIIIIIIIIIIIIIIIII \\
Sep 2017 & 20 & IIIIIIIII IIIIIII \\
Oct 2017 & 9 & II IIII \\
Nov 2017 & 25 & IIIIIIIIIIIIII III \\
\hline
\end{tabular}

\section{Individual X-Chart before Improvement}

i. The process is stable as, there is no outlier point in the control chart.

ii. The process has variation and questioned for capability Figure 3.

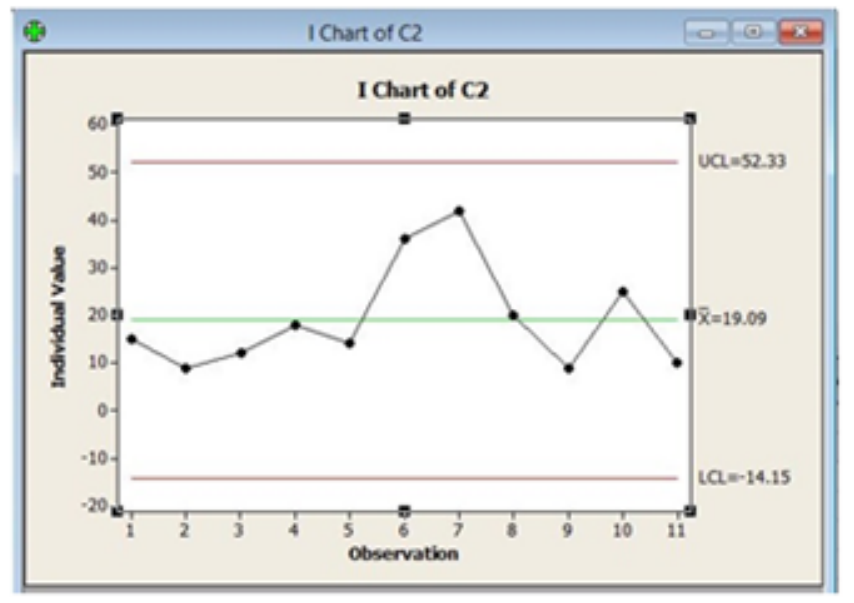

Figure 3 Individual X- chart before improvement.

\section{Analyze phase}

(Figures 4-6) \& (Table 7)

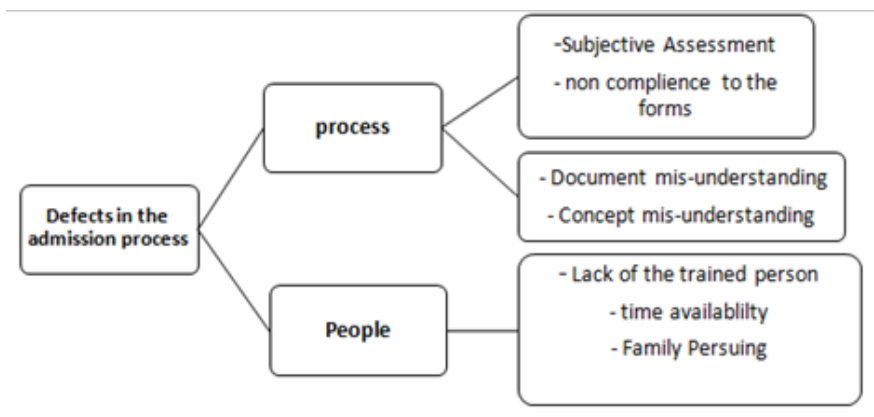

Figure 4 Brain storming.

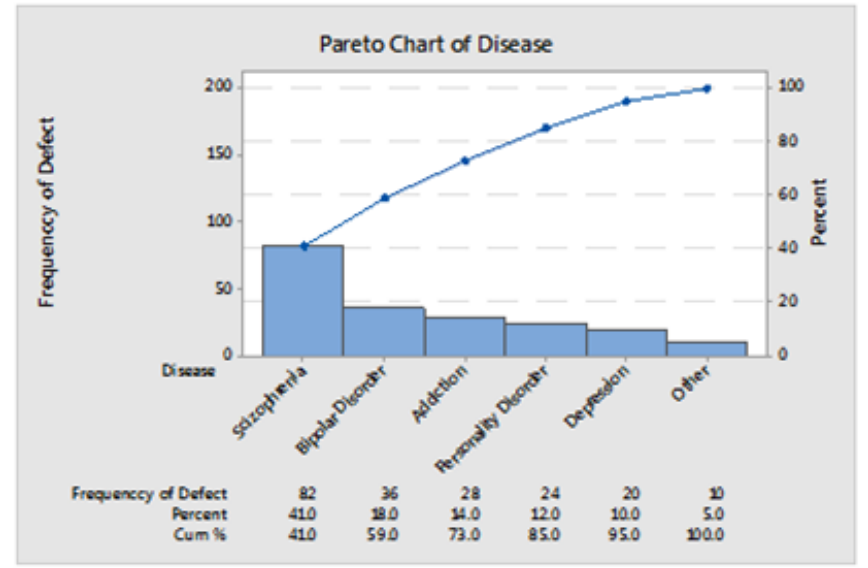

Figure 5 Pareto diagram.

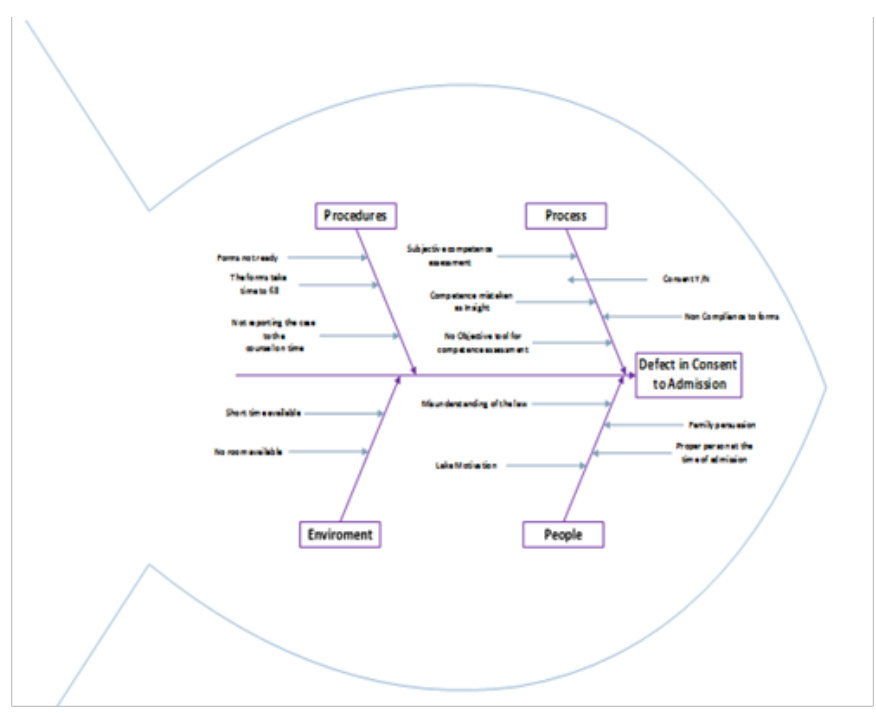

Figure 6 Fish bone analysis.

Table 7 Pareto Table

\begin{tabular}{ll}
\hline Defects Reported with Diagnosis & frequency \\
\hline Schizophrenic's Patients & 82 \\
Bipolar Disorder's Patients & 36 \\
Depression`s Patients & 20 \\
Personality disorders' Patients & 24 \\
Addiction's Patients & 28 \\
Obsessive Compulsive Neurosis`s Patients & 10 \\
\hline
\end{tabular}

\section{Improve phase}

The Root causes analysis revealed that, Schizophrenia is the most prevalent diagnosis with the reported defects as regards the type of admission (Involuntary admission). The factors related to the defect in admission of such a diagnostic group are the misinterpretation of the concept of the insight, usually lacking in those patients with the other different concept, the Competence. The remedy of this problem needs either an objective instrument for the assessment of the competence to consent for admission or the assessment by the presence of a more expert psychiatrist, a consultant level. 


\section{Remedy selection matrix}

i. The selected solution is a forensic instrument named MacArthur competence assessment toll for objective evaluation of competence according to the requirements of the Egyptian Mental Health law (Table 8).

ii. The instrument is a scale would be available in a printed form with the resident psychiatrist for the objective competence assessment and examining the patient's ability to give an informed consent for the admission $t$ the mental ill hospital (Figures 7-10).

Table 8 Remedy selection matrix

\begin{tabular}{llll}
\hline Criteria of & Weight & $\begin{array}{l}\text { Objective } \\
\text { Competence } \\
\text { assessment } \\
\text { By Resident } \\
\text { Psychiatrist } \\
\text { Using Forensic } \\
\text { Instrument Form }\end{array}$ & $\begin{array}{l}\text { Evaluation by } \\
\text { Consultant } \\
\text { Psychiatrist }\end{array}$ \\
\hline Cost & 10 & 9 & 1 \\
Effectiveness & 10 & 9 & 9 \\
Benefit & 10 & 9 & 9 \\
Risk & 5 & 4 & 1 \\
Total Score & & 290 & 195 \\
\hline
\end{tabular}
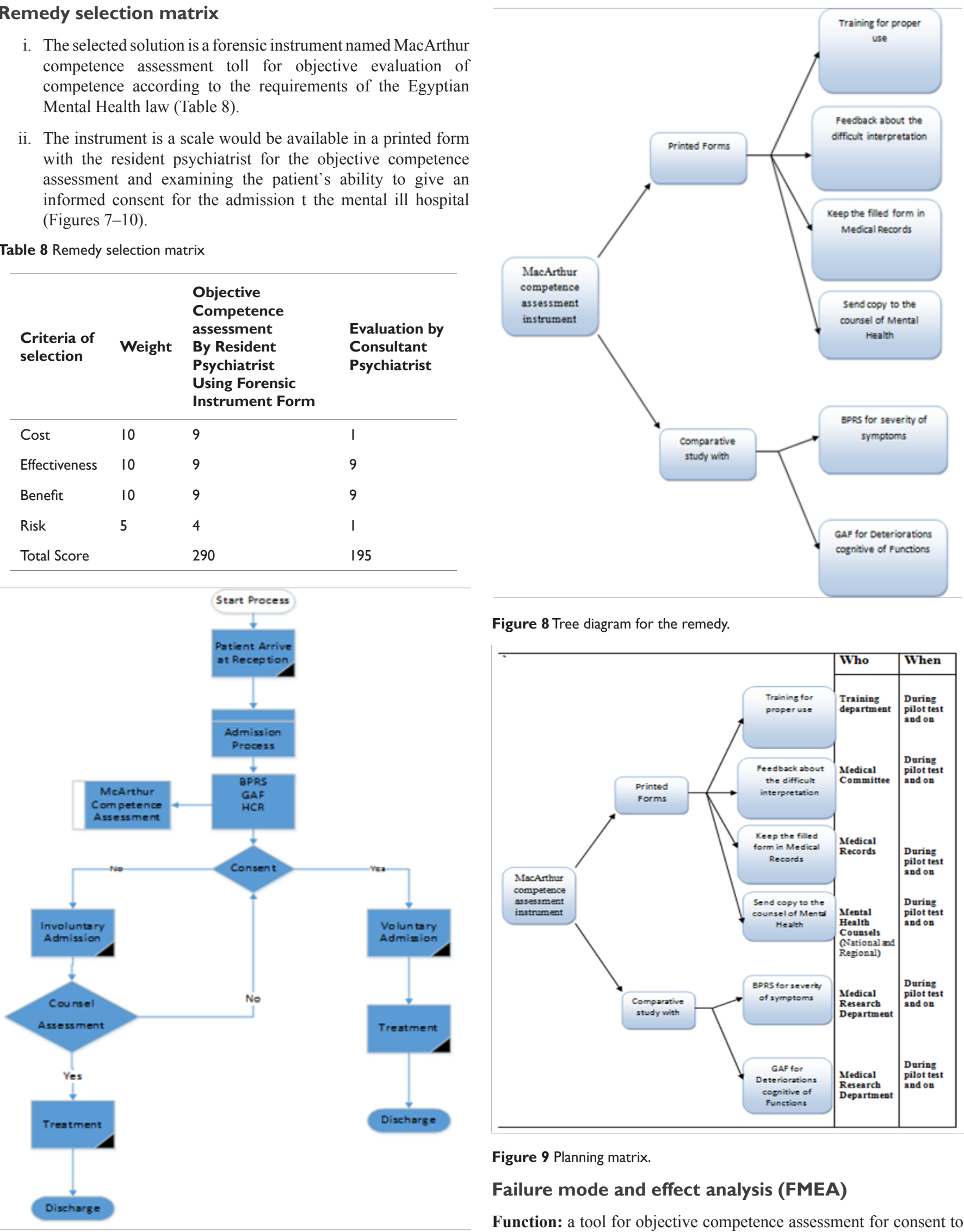

Figure $\mathbf{8}$ Tree diagram for the remedy.

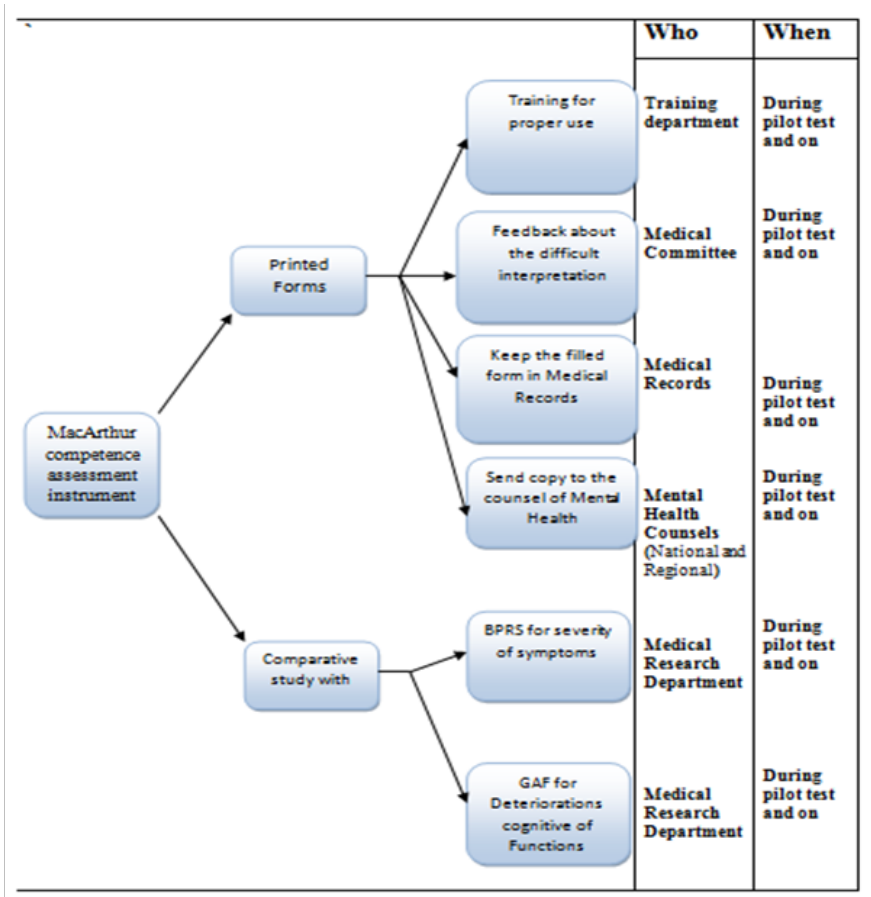

Figure 9 Planning matrix.

\section{Failure mode and effect analysis (FMEA)}

Function: a tool for objective competence assessment for consent to admission (Table 9).

Figure $7 \mathrm{New}$ detailed flow chart after improvement. 


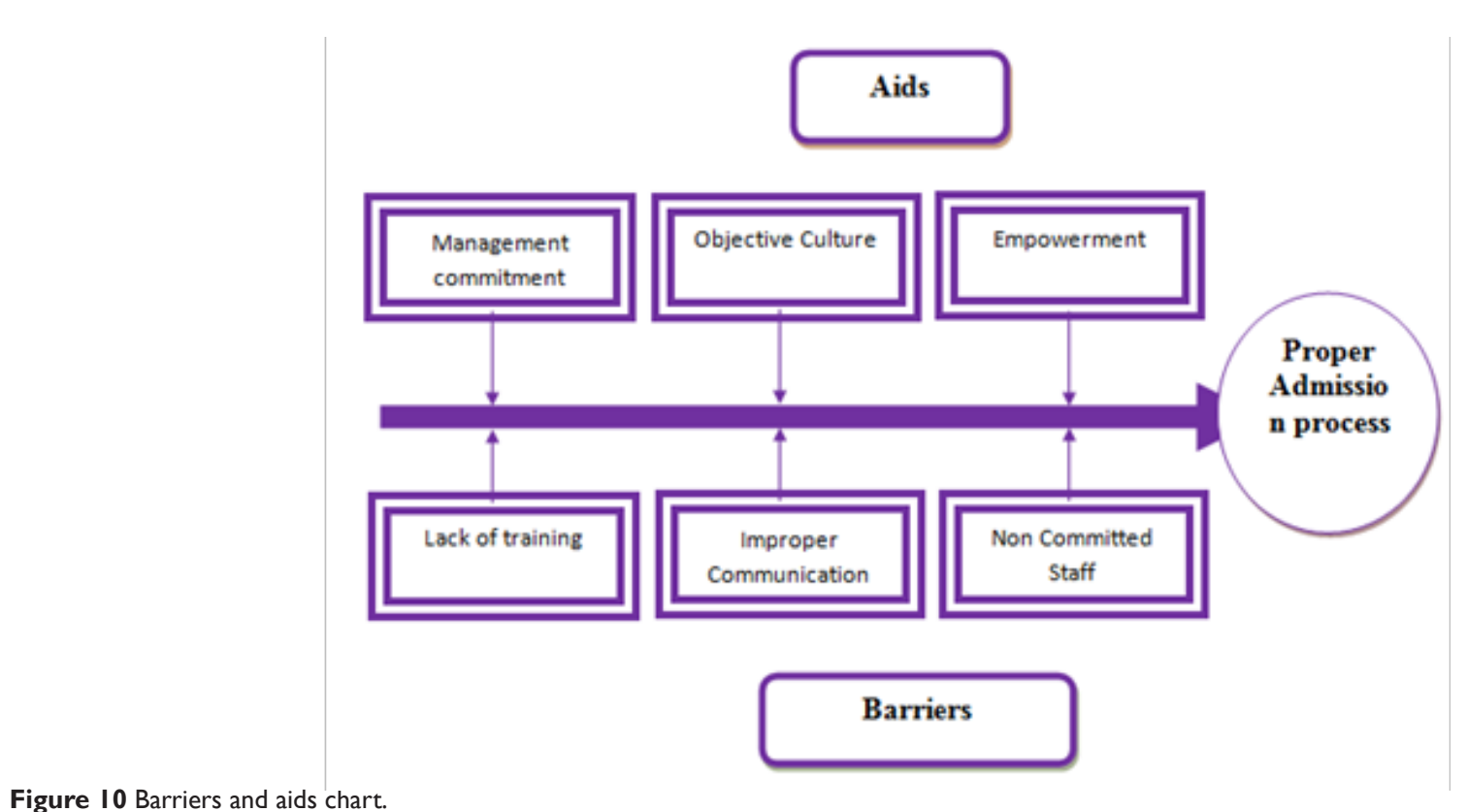

Figure 10 Barriers and aids chart.

Table 9

\begin{tabular}{|c|c|c|c|c|c|c|c|c|c|}
\hline $\begin{array}{l}\text { Process } \\
\text { step/input }\end{array}$ & $\begin{array}{l}\text { Potential } \\
\text { failure } \\
\text { mode }\end{array}$ & $\begin{array}{l}\text { Potential } \\
\text { failure effect }\end{array}$ & $\begin{array}{l}\text { Potential } \\
\text { causes }\end{array}$ & occurrence & severity & detection & RNP & Design action & $\begin{array}{l}\text { Design } \\
\text { validation }\end{array}$ \\
\hline $\begin{array}{l}\text { Objective } \\
\text { assessment of } \\
\text { Competence } \\
\text { using the } \\
\text { MacArthur } \\
\text { form }\end{array}$ & $\begin{array}{l}\text { Non proper } \\
\text { application of } \\
\text { MacArthur } \\
\text { form }\end{array}$ & $\begin{array}{l}\text { Risk of wrong } \\
\text { admission } \\
\text { categorization } \\
\text { (Involuntary) }\end{array}$ & $\begin{array}{l}\text { No full } \\
\text { participation } \\
\text { of team }\end{array}$ & 3 & 10 & 2 & 60 & $\begin{array}{l}\text { The resident } \\
\text { Psychiatrist has } \\
\text { to go through } \\
\text { the MacArthur } \\
\text { form to assess } \\
\text { competence } \\
\text { based consent }\end{array}$ & $\begin{array}{l}\text {-Auditing by } \\
\text { the consultant } \\
\text {-Auditing by } \\
\text { the counsel }\end{array}$ \\
\hline
\end{tabular}

\section{Proving effectiveness and pilot testing}

The project team prior to the final implementation of the new improved process decided to test its effectiveness in order to unmask the following:

i. Feasibility for implementation of the new improved process decided in the reality context

ii. Explore resources that might be needed for the full implementation of the process.

iii. The acceptance of the users for the new process and the level of commitment needed by each user to reach full implementation.

iv. The barriers identified as to the full implementation of the process.

v. The effectiveness of the new process to meet its desired improved outcomes

vi. The team selected the pilot testing in view of its accuracy and realistic features.

\section{Implementation}

After the pilot testing the project team is ready to begin full scale implementation. Before implementation of the new improved process the project team addressed the following issues leaned from the pilot study: i. Barriers determined.

ii. Countermeasures addressed.

iii. Process prove efficacy under ideal performance conditions.

iv. Leadership and commitment for the full implementation phase in order to define the accountability.

\section{Changes inflicted by implementation requires}

i. Clear plans for deployment and Empowerment.

ii. Change management plan.

iii. Clearly written and documented procedures.

\section{Preparations}

i. Involvement of process owners (Admission team)

ii. Training for the end users (Resident Psychiatrists) to obtain the desired outcome.

Change in processes that involve:

1. Change in the working methodologies.

2. Roles plays are essential (Table 10 \& Figure 11).

\section{The control chart is displaying that}

i. The process is Stable after the improvement 
ii. The process gets more capable and the variation is minimized (Figure 12).

\section{New Sigma Level to be calculated}

I. According to data collected in the pilot testing and early implementation:

II. Total number of units $=100$

III. Opportunities for defect per unit $=4$

Table 10 Control Phase
IV. Numbers of defects (non-compliance) $=4$

V. $\mathrm{DPU}=5 / 100=0.05$

VI. $\mathrm{DPO}=5 / 100 \times 1 / 3=0.016$

VII. $\mathrm{DPMO}=166$

VIII. Sigma level $=\mathbf{3 . 8 3}$ (Yield $99 \%$ ) compared to sigma level before improvement that was $\mathbf{3 . 5 5}$ (Yield 98\%).

\begin{tabular}{lllllll}
\hline Control variable & How measured & $\begin{array}{l}\text { Where } \\
\text { measured }\end{array}$ & Standard & $\begin{array}{l}\text { Who } \\
\text { analyze }\end{array}$ & Who acts & What done \\
\hline $\begin{array}{l}\text { During admission process; the } \\
\begin{array}{l}\text { Clinical versus the objective } \\
\text { assessment of competence }\end{array}\end{array}$ & $\begin{array}{l}\text { MacArthur } \\
\text { objective } \\
\text { assessment form }\end{array}$ & $\begin{array}{l}\text { Preadmission } \\
\text { room } 3\end{array}$ & $\begin{array}{l}\text { relevant Score is written } \\
\text { to explain the type of } \\
\text { admission }\end{array}$ & $\begin{array}{l}\text { Resident } \\
\text { Psychologist }\end{array}$ & $\begin{array}{l}\text { Resident } \\
\text { Psychologist }\end{array}$ & $\begin{array}{l}\text { Systematic questions } \\
\text { and filling the form } \\
\text { and calculating a score }\end{array}$ \\
\hline
\end{tabular}

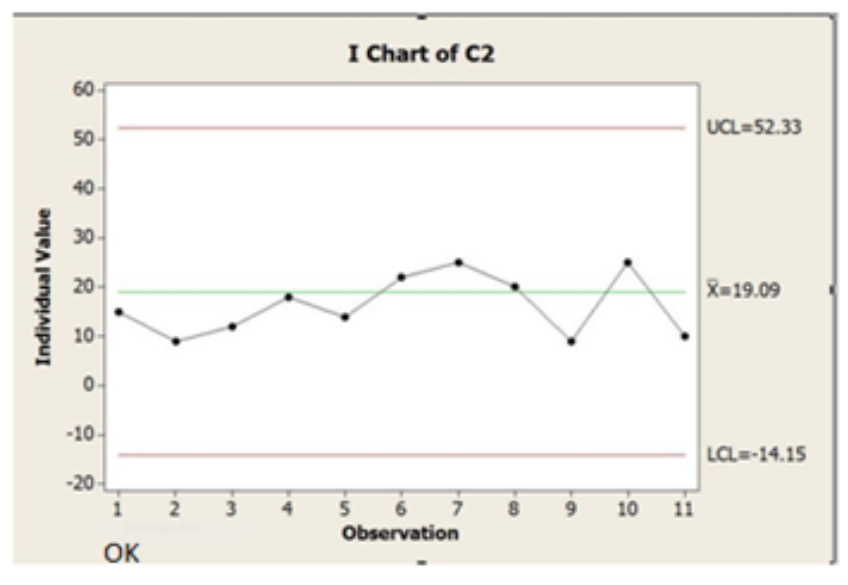

Figure II Individual X-Control chart after improvement.

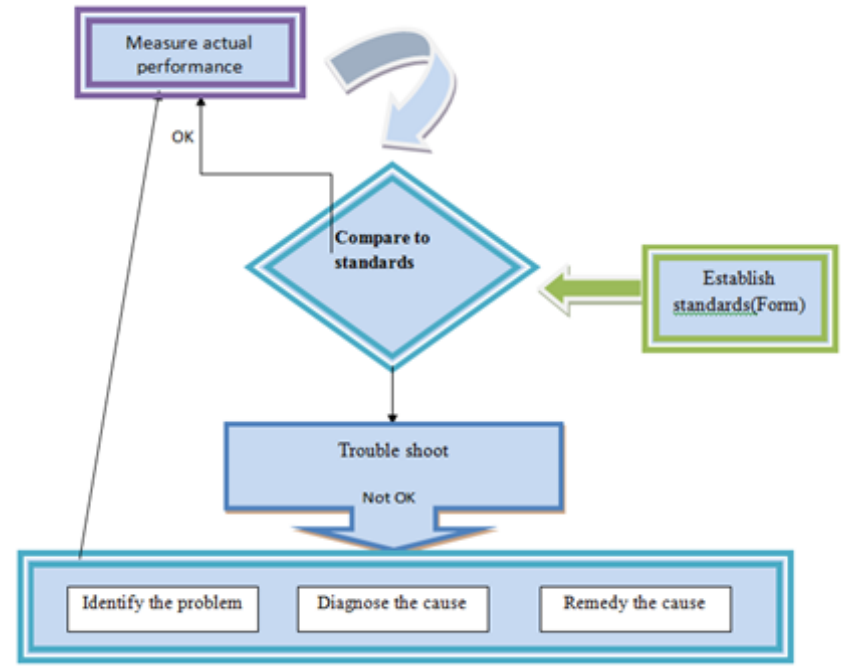

Figure 12 Audit the control feedback loop.

\section{Summary and conclusion}

I. After legalization of the Egyptian Law of the Care of the Mentally Ill Patient, this is the first effort to measure competence of making admission`s decision in Egypt with the use of standard and objective assessment tools. ${ }^{1}$

II. The current project is aiming for improvement the compliance to the new Egyptian law by objective assessment of the competence.

III. The project improved the performance of the psychiatrists in taking consent for the admission to the mental ill hospitals.

\section{Recommendations}

The compliance to the conditions of the Updated Egyptian Mental Health Law $^{5}$ through an objective assessment tools though proved it effectiveness to improve the performance and reduce the money leak in the mental health facilities, yet it requires more training and continuous improvement using this new tool (MacArthur assessment tool) and to search for more types of improvements in the process of admission.

\section{Acknowledgments}

None

\section{Conflicts of interest}

The author declares that there are no conflicts of interest.

\section{References}

1. Elghazali AM. Objective Forensic Assessment of Competence versus Severity of Symptoms and Assessment of Functioning for Schizophrenic Inpatients based on Egyptian Law. Forensic Research and Criminology International Journal. 2015;1(1).

2. Appelbaum P, Grisso T. Assessing patients capacities to consent to treatment. New England Journal of Medicine. 1988;319(25):1635-1638.

3. Declaration on the Rights of Mentally Retarded Persons, Proclaimed by General Assembly resolution 2856 (XXVI) of 20 December. 1971.

4. Pyzdek T, Killer P. "The Six Sigma Handbook, a complete guide for green belts, black belts and managers at all levels". 2009.

5. World Health Organization. Resource Book on Mental Health, Human Rights and Legislation. Section 7.1. Mental Disability Advocacy Center. Human Rights and Guardianship in Bulgaria. 2006. 